\title{
Ethical reflexivity in qualitative research: the use of cinematographic movies as an instrument for continuous training
}

\author{
Reflexividade ética na pesquisa qualitativa: o uso de filmes cinematográficos como instrumento de formação continuada \\ Reflexividad ética en la investigación cualitativa: uso de películas cinematográficas como un instrumento de \\ capacitación continua
}

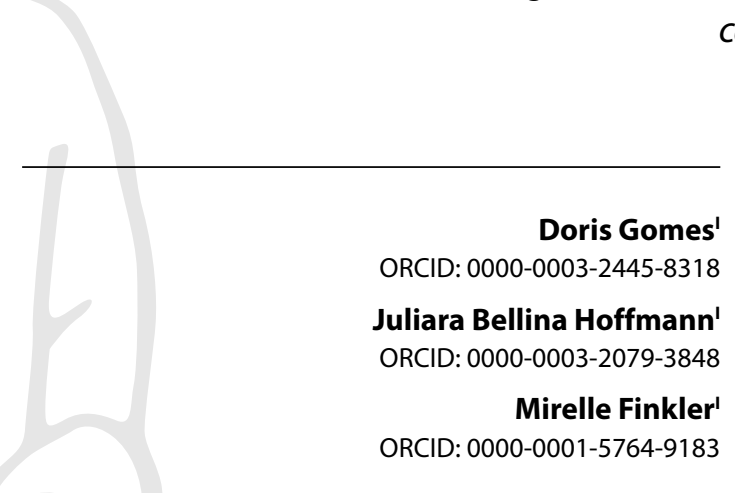

'Universidade Federal de Santa Catarina. Florianópolis, Santa Catarina, Brazil.

How to cite this article:

Gomes D, Hoffmann JB, Finkler M. Ethical reflexivity in qualitative research: the use of cinematographic movies as an instrument for continuous training. Rev Bras Enferm. 2021;74(3):e20190146. https://doi.org/10.1590/0034-7167-2019-0146

Corresponding author: Doris Gomes

E-mail:dorisgomesodonto@gmail.com

EDITOR IN CHIEF: Dulce Barbosa ASSOCIATE EDITOR: Margarida Vieira

Submission: 05-10-2019 Approval: 01-09-2021

\begin{abstract}
Objectives: to analyze ethically, aesthetically and politically the cine-debate of the movie "Human", reflecting on training of researchers in qualitative research. Methods: the debate about moral questions as the essence of humanity was based on Narrative Bioethics; the comprehensive, relational and reflective character of qualitative methods; and the ethical and social sense of qualitative researches. Results: the narratives of the experiences of morality, loaded with facts and valuations, highlighting the importance of reflexivity in all phases of the qualitative research process, from thinking about themes and research questions to fieldwork, from data analysis to the production of reports, fostering the researcher's responsibility both in the intervention for understanding and narrating the world, and in its possible transformation. Final Considerations: cinematographic art becomes an instrument of reflexivity capable of affecting and mobilizing students, in a fusion of horizons of understanding of different universes that dialogue.
\end{abstract}

Descriptors: Research, Qualitative; Bioethics; Ethics; Motion Pictures; Education, Continuing

\section{RESUMO}

Objetivos: analisar ético-estético-politicamente o cine-debate do filme "Human", refletindo sobre a formação crítica dos investigadores na pesquisa qualitativa. Métodos: fundamentou-se na Bioética Narrativa o debate em roda das questões morais, como a essência da humanidade, o caráter compreensivo, relacional e reflexivo dos métodos qualitativos e o sentido ético e social das pesquisas qualitativas. Resultados: as narrativas das experiências de moralidade, carregadas de fatos e valorações, destacam a importância da reflexividade em todas as fases do processo da pesquisa qualitativa, do pensar temas e pergunta de pesquisa ao trabalho de campo, da análise dos dados à produção dos relatórios, fomentando a responsabilidade do pesquisador, tanto na intervenção para a compreensão e narração do mundo, quanto na sua possível transformação. Considerações Finais: a arte cinematográfica torna-se instrumento de reflexividade capaz de afetar e mobilizar, em uma fusão de horizontes de compreensão de universos diferentes que dialogam.

Descritores: Pesquisa Qualitativa; Bioética; Ética; Cinema; Educação Continuada.

\section{RESUMEN}

Objetivos: analizar ético-estético-políticamente el cine-debate de la película "Human", reflexionando sobre la capacitación crítica de los estudiosos en la investigación cualitativa. Métodos: el debate en rueda de las cuestiones morales se fundamentó en la Bioética Narrativa, como la esencia de la humanidad, el carácter comprensivo, relacional y reflexivo de los métodos cualitativos y el sentido ético y social de las investigaciones cualitativas. Resultados: las narraciones de las experiencias de moralidad, cargadas de hechos y valoraciones, resaltan la importancia de la reflexividad en todas las fases del proceso de la investigación cualitativa, desde el elucubrar sobre el tema y la pregunta de la investigación hasta el trabajo de campo; desde el análisis de los datos hasta la producción de los reportes, incentivando la responsabilidad del investigador, tanto en la intervención para la comprensión y narración del mundo, como en su posible transformación. Consideraciones Finales: el arte cinematográfico se convierte en un instrumento de reflexividad capaz de afectar y movilizar en una fusión de horizontes de comprensión de diferentes universos que dialogan. Descriptores: Investigación Cualitativa; Bioética; Ética; Películas Cinematográficas; Educación Continua. 
From the proposal for a cine-debate to the promotion-training of reflexivity

As movies bring different dimensions of reality and their multiple meanings, they become important vehicles of communication, expression and perception of the world. Qualitative research, in the search for understanding the study reality and context, promotes the training of the researcher while developing its own method. As part of the program of the VIII Iberoamerican Congress of Qualitative Research in Health, which took place in the city of Florianopolis-SC-Brazil in 2018, a cine-debate of the movie "Human" was promoted. The documentary released in 2015 has been proposed since its launch to also be used as an educational project. From 40 years of photographs of the planet and human diversity, director Yan Arthus-Bertrand - photographer, environmentalist and founder of Foundation Good Planet, in partnership with Foundation Bettencourt Schueller (both non-profit organizations) and France Television, sought to consider why humanity does not move towards harmonious coexistence. In addition to statistics, the answer was found in the life stories captured by his lens: unique and experiential(1).

With the involvement of a total of 16 journalists, 20 camera operators, 5 editors and 12 more people, the director recorded and synthesized 500 hours of aerial shots and 2000 hours of interviews, conducted over 18 months, with 2020 people, in 60 countries and 63 languages. The documentary takes a multicultural journey across the planet, without a pre-established script, building a filmic narrative of human universality, based on the singularities of each interviewee and their lives. Stories that mix through different identities and places, but that seek in common sense, recognition, acceptance and appreciation. It is a narration in three poetically intertwined voices: human beings, land and music, forming an invitation to pause, introspection and debate ${ }^{(1)}$.

"Human" is an interesting tool for continuous education to approach ethical reflexivity in qualitative research, understood as constant attention on how and what happens in the empirical context that affects the researchers and their work, which affects the country and social life ${ }^{(2)}$. The expression of the researchers' awareness of their connection with the research, in a process of turning to themselves to critically analyze their effect on the research, the impact of their interactions with the participants and the interaction-repercussion of their research with the real world goes through all levels and phases of the study. Reflexivity appears as a quality criterion for qualitative research, as well as a human skill that must be learned and developed, and this is a central component in the training of investigative professionals ${ }^{(3)}$.

This reflection seeks to deepen the ethical-aesthetic-political analysis initiated in the pedagogical-collective activity developed in that Congress, instrumentalizing (self) criticism committed to qualitative health research, protagonists in the construction of subjectivities and conformation of researchers. The proposed activity invited interested parties to watch the third version of "Human" (with free access, made available by producers via YouTube), which deals with the themes of love, female life, work and poverty. A total of 22 people accepted the invitation and then participated in a conversation group analyzing and connecting the movie to reflexivity, qualitative research and the training of researchers.
The question "what makes us human?" structures and attributes consistency to the movie, triggering the problematization of concepts and contexts related to reflexivity, such as: diversity, complexity, plurality, uniqueness, conditioning, self-determination, brotherhood, solidarity and humanity, as well as referring to the meaning of quality: a set of fundamental properties linked to being, inserted in a certain object or phenomenon and indicative of the limits that separate one from the other, causing its modification, in the radical modification of the object or phenomenon ${ }^{(4)}$. Phenomena or facts, although they can be considered objective external events, are not of interest to science, but because they are attributed social relevance (value), adding a scientific perspective and transforming them into constructs relationships that go beyond mere fact, to make them value. Thus, the property of qualifying, related to the perceptions of individuals about the different factors of life (social, cultural, economic, relational), is influenced by the needs and expectations of the observer or researcher, their wants, desires, objectives and interests. This leads researchers who use qualitative methodologies to make ethical citizenship commitments to people and the themes they work with ${ }^{(2)}$.

Globalization and the migration of people around the world, while fostering moral plurality at the same time, place issues such as difference, diversity and care in a certain centrality within the scope of social research, amplifying the importance of the qualitative approach, already widely used in some areas of health ${ }^{(5)}$. In the vast field of scientific knowledge, qualitative research raises questions and reflections on the complexity of humans as living beings immersed in relationships, environments and contexts, that is, in their social praxis. A reiterated and irresistible invitation to reflexivity that brings the movie "Human" closer to qualitative methodologies. In this perspective, it seeks to apprehend the human condition and reflect on the meaning of its existence, the role of the researcher and the qualitative research, starting from human beings as real and social historical subjects who creates and recreates themselves, "Endowed with meanings and poten-

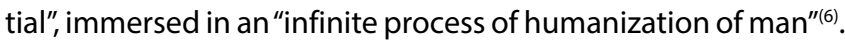

\section{Script and action: foundations and methodological strategies}

The use of cinema in the education of health professionals is not recent, the first publication on its use in medical education was in 1979 . However, since the 2000 s there has been an important increase in this type of non-traditional pedagogical strategy, aimed at maintaining the students' attention and generating discussion on relevant topics, such as an active methodology ${ }^{(6)}$ and education. A look that is movement in itself, with formative, critical, reflective and transformative power, based on the questions it raises and the problematic ethical positioning that emerges from it. Cinema and the experience of the cine-debate open the possibility for participants to consider their involvement in the processes of knowledge and humanization (7).

Thus, cinema is transformed into a powerful instrument of approximation to the real, either by the seduction of artistic language or by the subtlety and forcefulness of narratives. Through them, it is allowed to "reveal the human existence as 
a narrative - temporal, circumstantial, concrete, full of emotion and life - allowing the distance from the narrow margins within which society has thought the reason"(8). The use of cinema, guided by hermeneutical-inspired Narrative Bioethics - which is based on key concepts such as responsibility and deliberation -, becomes an instrument of access to the plurality of reality and the diversity of perceptions and perspectives; exploration of multiple experiences away from pure positivism; imagination as a way of knowing and deepening reality; experimentation with the unknown; possibility of dialogue (between the knowledge of the movie and that of the viewer); and also cultural translations, interpretation of experiences and different places ${ }^{(8)}$. Showing images and social representations, we ask who are the vulnerable in each work, if they live in social life, what relationships are established and what are our responsibilities. The documentary movie can condense knowledge and sensory and sensitive reflexes for greater proximity to social representations ${ }^{(9)}$.

Based on this framework, the Group Method was used to stimulate and facilitate the debate among the participants: the group as a democratic space for the circulation of the word, as a way of co-management and co-production and in permanent movement. Following the analysis of the movie proposed by Flick $^{(10)}$, two readings were developed: a realistic reading of the stories that make up the movie or a true description of the phenomenon, with its meaning being revealed by an accurate analysis of the contents and formal aspects of the images; and a subversive reading, highlighting the author's ideas that may have influenced the film and those of the performers that may influence the interpretation.

In this cine-debate, the participants initially received informational material on the origin, objectives and preparation of the movie "Human". Subsequently, the cinematographic work was presented and its election was justified related to the intentionality of the work proposal. In view of the diversity of themes raised by the movie and as a way to guide its appreciation and operationalization of the subsequent debate, it was suggested the observation of axes of analysis related to the question of reflexivity in research: moral issues as the essence of humanity; the comprehensive, relational and reflective character of qualitative methods; and the ethical and social sense of qualitative research. After watching to the movie, the participants repositioned themselves in a circle to collectively analyze and share their perceptions work by work, while drawing a parallel between scenes, speeches, looks and qualitative research and its challenges. In this process, we sought to increase the perspective of each and everyone. The debate was mediated to stimulate the participation of the greatest number of interlocutors, articulating the different views and, mainly, focusing on the object in question.

\section{Between movie and words: the debate about qualitative research based on art and art as a result of research}

"Human" is a work of art designed and built similar to a research process in the social and human sciences. Following a previous script of concatenated questions, the movie is constructed as part of the restlessness of its creator, in the search for answers only understood from human contact. Frequently, the viewer feels like an anthropologist in the middle of a research field. A situation of similarity that unfolds throughout the movie: in the look as a focus of convergence; in listening to words and silences; observation of expressions; in the authentic interest in the narratives; in the attribution of meanings; in the search for what is singular and, at the same time, universal; in the sewing of speeches; in the grouping of themes; in ethical directionality; and the political objective of the intervention. This empathic perspective between director and researcher, sometimes seems to change between interviewees and viewers as, in front of the eyes centered on the screen, the audience becomes the object of intervention in the documentary. Art as an instrument of reflexivity, as a resource to affect and mobilize the other through a fusion of horizons of understanding, reveals these two universes - science and art that talk or that can complement each other.

In qualitative research, there is a constant need for judgments and decision making about the best path to follow, so there is a need to keep an open mind, expect the unexpected and have a reflective attitude. The speech designates specific forms of construction of meanings that can occur through oral and written language, but also visual, auditory and gestural. In the movie, the sequence of looks, "inter-views", mouths and faces that speak as much as the interviewees' speeches, star in the scenes, highlighted by a unique light that focuses precisely on what we want to highlight: the humanity we capture in the expression of the reason and emotion of the other. Another that sustains its look towards the camera, that sustains its silence, its suffering, its desires and expectations, values, needs and desires. By doing so, it requires reciprocity: in recognizing the other, we also recognize ourselves; when we think about the meaning of life and existence attributed by the other, we think about our own.

This introspection is favored by the scenes of landscapes that intersect the interviews, demarcating together with the musicality "chapter passages", always conformed by the presence or direct interference of people and initiated by preambles that introduce the viewer to a new question to be answered in the next chapter. The hidden question that gives rise to this passage does not need to be heard to be understood, as it is supported by the space of telling and listening to stories. The scenes allow us to glimpse countless approaches or interpretations, such as crossing a suspension bridge, suggesting the difficult, tortuous and insecure paths of life and of qualitative research itself, and producing meanings for the researchers-viewers.

The intention of the producers of documentary-art seems to have been that the composition among the lines, the music and the landscapes would sharpen the five human senses: in the bitter taste of hunger and the exuberant and wicked inequality; the smell of places and people left behind; in the heat and cold that accompany the symbolic landscapes of the brevity of human life; in the vision of the scar left by the plow in the soil, of the clothes spread on the ground, of the flowers being harvested, of the human work that extracts subsistence on the earth; in the multicultural sounds that build a sense of unity for humanity.

Emotion, aesthetics and poetics mix. Scenes that seem to seek a counterpoint between the extraordinary dimensions of nature and that of the human being, selected from a perspective focused on human work and life. Scenes that are amplified in 
everyday life, that resize the human in nature, in humanity and in time. Scenes that refer to the complex web of relationships, to the power of human domination over nature and over itself, as a social being, while submitting to the strength and immensity of landscapes. Scenes that suggest hidden and intertwined understandings, waiting for discovery, meaning assignment, requiring intervention and begging for transformation. A tangle that refers to the making of qualitative research, from the initial chaotic view to the lines that need to be unveiled, to the mooring that takes place among participants, research object and researcher.

\section{The researcher's reflexivity as a permanent and unfini- shed task}

In the face of the competitiveness imposed on contemporary life, capitalistically subsumed to a hedonism that categorizes, stigmatizes and excludes people or groups of individuals by their power (or not) of "buying", the public spaces for social interaction and meetings that are permissible for telling stories are reduced. For this reason, the importance of qualitative research and the use of this movie as inducers of ethical-political reflection would already be justified. However, this documentary-art or research-art-documentary achieves what is intended with qualitative research: that others feel what the researcher can feel, that others see through their eyes and that they listen through their ears, understanding the realities in focus. Rationality and emotions that cry out for the researcher's ethics in the face of the researched, their context and life history, establishing trust and thinking critically. In the collective space of debating the movie, it was possible to reflect on qualitative research, as well as the importance of the reflective process inserted in research as an action process ${ }^{(2)}$.

As in qualitative research, researchers and subjects are transformed by meetings and research process, reflexivity becomes a critical theme and an endless task. Therefore, reflexivity, exercised in or by research,"requires the contextualization of subjects and phenomena in time and space, and an interactive and intersubjectivity posture by the researcher ${ }^{\prime \prime(2)}$. The practice of reflexivity is marked by inter-subjectivity and universal solidarity, becoming permanent in qualitative research, and it is not possible to isolate the knowledge produced from the person who produced it. Thus, theory and method become integrated, considering that the method is not a set of rules or recipes to be followed, but a continuous and theoretically founded reflection on the social practices and relationships researched.

Ethics and science must be seen as regulatory ideas for a high abstraction, not just as a synonym for models or norms to be followed ${ }^{(2,6)}$. Since "knowledge is not contemplation", but an expression of human praxis, where men are part of nature at the same time that they surpasses it, behaving freely with their own creations, they seek to stand out from them and raises the problem of their meaning, seeking to discover their own place in the universe ${ }^{(4)}$. The reflexivity permanently present in the qualitative research work leads researchers to observe themselves, as well as their behavior in the field, with respect to their interlocutors, making a two-way process: researchers know people and communities under study, modifying themselves in the knowledge construction process, at the same time that they become known by them, being able to modify their life and action processes. Thus, in addition to the methods and techniques, the actors, the authors involved in the knowledge process are taken into account, making up the action of understanding, interpreting, reporting and disseminating results.

The scientific view must submit the world of representations and common thought to an examination that goes beyond its immediate aspects, reaching a place where "the reified forms of the objective and ideal world are diluted, lose their fixity, naturalness and alleged originality, to show themselves as derived and mediated phenomena, as sediments and products of humanity's social praxis"(4).

Thus, reality is not conceived as a state already realized and out of time, clinging to given and predestined truths, ready and finished, imprinted in an immutable way in human consciousness, but as part of a process in the course of which humanity and the individual realize their own truth, operating the humanization of men: a world in which the truth owes. Destroying a pseudo concreteness of "reified" worldly things and phenomena, the truth becomes neither unattainable nor attainable once and for all, but it is being done, developing and realizing from a thinking that seeks unveiling beyond reified men, in objectified, illusory and apparent relationships. Therefore, a non-fetishized reflection is needed, which perceives the creation of the human environment as a human fact, with conditions of transparent rationality that change the manipulated praxis ${ }^{(4)}$.

When the movie proposes to expose human diversity, it removes the veil of invisibility, especially placed on the vulnerable of the earth and the Earth - audience that makes up the movie. Toothed, albino, yellow, white, black or brown faces; wrinkles, smiles and tears; clothes and props that tell us about their different concepts of happiness, their anguish and the countless moral values, with survival and culture. The narratives of the experiences of morality, loaded with facts and valuations, highlight the importance of reflexivity in the research process, in all its phases, from thinking about themes and research questions to fieldwork, from data analysis to production reports, fostering the researcher's responsibility, both in the intervention for the understanding and narration of the humanized world, and in its possible transformation.

This aspect leads to a critical reflection on the very social effectiveness of research, in which it seeks to give centrality to the meeting, the interview, the listening, that is, the subjectivities and inter-subjectivities that are manifested beyond words and that, in this meeting, recreate themselves. The identification of the meaning and impact of the subjects' participation in "Human" is explicit in the final scenes and speeches, which refers to the effect that qualitative research has on the subjects who participate in it, raising the need for this identification, implication and return.

\section{FINAL CONSIDERATIONS}

The practice of reflexivity in qualitative research becomes a means by which the knowledge produced and the researcher who produced it can be understood as the construction and result of the investigative process. A perception that refers to the 
need for critical reflection on the social effectiveness of research, both for individuals, communities and researchers, and for the development of science. At the same time that the presentation of research results in audiovisual format is suggested, as a new ethical-aesthetic-political possibility of art mixed with science, social, human and health research is perceived as a science that can be intertwined with art, especially in its formative and reflective aspect.

\section{REFERENCES}

1. Bettencourt Schueller Foundation. Goodplanet Foundation. Human [Internet]. 2015 [cited 2019 May 10]. Available from: http://www. human-themovie.org

2. Minayo MCS, Guerriero ICZ. Reflexividade como éthos da pesquisa qualitativa. Ciênc Saúde Coletiva. 2014;19(4):1103-12. https://doi. org/10.1590/1413-81232014194.18912013

3. Silva-Satlov I, Rivera Pérez R. Alfabetización científica para la salud global. una reflexión respecto a la formación en investigación. Interface (Botucatu). 2019;23:1-9. https://doi.org/10.1590/Interface.170444

4. Kosik K. Dialética do Concreto. Rio de Janeiro: Paz e Terra; 2002. 250 p.

5. Souza CJ, Silvino ZR. The production of the professional master's degree in nursing of the Federal University of Santa Catarina, $2013-2016$. Rev Bras Enferm. 2018;71(suppl 6):2751-7. https://doi.org/10.1590/0034-7167-2018-0153

6. Mattos MP. Viagem educacional e oficinas temáticas como ferramentas de formação construtivista em psicofarmacologia clínica. Reciis Rev Eletron Comun Inf Inov Saúde. 2018;(4):478-88. https://doi.org/10.29397/reciis.v12i4.1448

7. Lobo MO, Garcez FCM, Bezerra AJC, Gomes L. Relação médico-paciente idoso no cinema: visões de atendimento. Rev Bioét. 2017;25(2):38291. https://doi.org/10.1590/1983-80422017252198

8. Hoffmann JB, Moratelli LB, Finkler M. Educação permanente em saúde: uma experiência do projeto "Bioética pelas Lentes do Cinema". Extensio. 2017;14(26):97-106. https://doi.org/10.5007/1807-0221.2017v14n26p97

9. Cerdá JM, Ramacciotti K. La enseñanza de Historia Social en la carrera de Enfermería. Interface (Botucatu). 2018;22(67):993-1002. https://doi. org/10.1590/1807-57622017.0464

10. Flick U. Introdução à Pesquisa Qualitativa. 4a ed. Porto Alegre: Artmed; 2009. 408 p. 